\title{
UNDERSTANDING CRITICAL VARIABLES CONTRIBUTING TO COMPETITIVE ADVANTAGES OF INTERNATIONAL HIGH-SPEED RAILWAY CONTRACTORS
}

\author{
Yanliang NIU ${ }^{1}$, Xiaopeng DENG ${ }^{2}$, Limao ZHANG ${ }^{3}$, Xiaochen DUAN ${ }^{1}$ \\ ${ }^{1}$ School of Economics and Management, Shijiazhuang Tiedao University, Shijiazhuang, China \\ ${ }^{2}$ Department of Construction and Real Estate, Southeast University, Nanjing, China \\ ${ }^{3}$ School of Civil and Environmental Engineering, Nanyang Technological University, Singapore
}

Received 25 November 2018; accepted 15 January 2019

\begin{abstract}
This article is devoted to identifying and explaining the critical variables contributing to competitive advantages in international High-Speed Railway (HSR) projects from the contractor's perspective. A total of 24 variables were identified by the literature review and a pilot study. An international questionnaire survey was performed to obtain professional opinions from both practitioners and the academy. The 24 variables were ranked and clustered into 6 factors using exploratory factor analysis. Furthermore, a case study of the Early Train Operator project of the California HSR was carried out by the survey, interview, and first-hand data. The results indicated that the top six ranked variables are (1) None Accident History, (2) Eligibility \& International Criteria, (3) Contract Reputation, (4) Marketing Strategy, (5) Risk Management Capability, and (6) Technical Responsiveness. Furthermore, the 24 variables are grouped into six dimensions: Glocalization, Marketing, Safety, Economics, Technology, and Responsibility. The case study indicated that the factor framework was suitable and tractable for the application. The findings of this paper could (1) assist international HSR contractors in obtaining a better understanding of the deeper determinates of competitive advantages and (2) serve as a valuable reference for developing their competitive advantages in the international HSR market.
\end{abstract}

Keywords: international project, high-speed railway, competitive advantages, critical variable, surveys, factor analysis, case study.

\section{Introduction}

Since the great Age of Discovery (navigation) and for more than 500 years, scientific and technological progress, the rise of the country, and the economic development have been closely related to the evolution of transportation (from ocean-going ships and steam locomotives, to diesel locomotives, high-speed railways, large aircraft, etc.). Today, because it is a fast and green transportation mode, high-speed railway (HSR) is listed as a strategic emerging industry with priority development all over the world.

There is strong international demand in the HSR market, with examples such as the California HSR Strategy in the USA, HS2 plan in the UK, the Mid-Term Railway Network Plan of China, the "Diamond Quadrilateral" strategy of India, and the "2050" Transportation Strategy of European Union. On the other hand, this huge market demand has attracted many competitors. For example, the bid for Mexico's HSR system has attracted the attention of 17 large, international consortiums; 12 international consortiums placed bids on India's HSR project, the "Diamond Quadrilateral"; and 35 consortiums have participated in bidding on the California HSR project. HSR contractors face extremely tough market competition. Therefore, it is very important to study how HSR contractors adapt to the era of global competition and stand out in this super-competitive environment.

Since Porter's (1985) milestone work, "Competitive Advantage", the term "competitive advantage" gained popularity in both business and academia. Porter (1990) believed enterprise capability was the composition and source of competitive advantage (Capability-Based View). This view (Green, Larsen, \& Kao, 2008; Kuo, Lin, \& Lu, 2017) recommended that an emphasis on core capability and competitiveness is the basis of competitive advantage and that the industrial structure and strategic positioning

${ }^{*}$ Corresponding author. E-mail: $d x p @ s e u . e d u . c n$ 
of enterprises are the main driving forces behind competitive advantage. Barney (1991), on the other hand, proposed the Resource-Based View of competitive advantage, which means that the resources owned by an enterprise are heterogeneous, and these heterogeneous resources are not mobile (Barney \& Mackey, 2016; Kellermanns, Walter, \& Crook, 2014); therefore, companies with valuable, scarce, inimitable, irreplaceable resources will gain sustained competitive advantage. With several schools of theories, the source of competitive advantage is mainly represented by Porter's capability-based view and Barney's resourcebased view.

In the research field of competitive advantage in construction, American Society of Civil Engineers (ASCE) appointed a task committee to assessed the impact of a global economy on competitiveness of U.S. contractors in 1988 (West, 1992), and the findings of the committee indicated that U.S. contractors may decline in domestic as well as international business unless corrective measures are taken. Flanagan, Lu, Shen, and Jewell (2007) provided a critical review of competitiveness in construction from the perspectives of industry level, firm level, and project level. Some studies focus on the competitive advantage of contractors in different countries or regions (Zhao \& Shen, 2008; Zhao, Zuo, \& Zillante, 2011; Orozco, Serpell, Molenaar, \& Forcael, 2014; Öz, 2001; R. Abdul, A. Abdul, \& Wong, 2010; Miozzo \& Dewick, 2002). Some studies deal with a competitive advantage in the field of toll road projects (Carpintero, 2011; Tiong, 1995).

However, few studies focusing on the competitive advantage of the international HSR contractors. In contrast to other construction projects, the competitive bidding of international HSR projects is not only an economic and technical issue but also involves political and social problems, which poses a challenge for the existing competitive advantage theory (Zhang, Deng, Zhao, \& Chang, 2018). Furthermore, gaining or maintaining a "contractor's" competitive advantage is not easy because it is determined by a large number of variables (Lu, Shen, \& Yam, 2008). Therefore, identifying and explaining the critical variables contributing to competitive advantages of international HSR contractors is a worthwhile research work.

To contribute to the knowledge of this issue, this paper offers a unique perspective of the competitive advantage of international HSR contractors. First, the study presents a literature review of the variables contributing to the competitive advantage. Subsequently, the research methodology is provided, and the data analysis and discussion are presented. In addition, a case study of the Early Train Operator project of the California HSR is performed by the survey, interview, and first-hand data. Finally, conclusions are provided and directions for future research are recommended. This research aims to discover and explain the critical variables contributing to competitive advantages in international HSR projects from the contractor's perspective.

\section{Literature review}

The existing research on HSR mainly focused on risk management and the application of technology. The application of technology related to: operation security (Rocha, Henriques, \& Calçada, 2015; Gou, Ge, \& Wang, 2016; Wu, Jiang, \& Shi, 2016), HSR network topology (Cañizares, Pita, \& Álvarez, 2015), inductive power transmission systems (Kim, B. S. Lee, \& J. H. Lee, 2015; Guzinski, Diguet, \& Krzeminski, 2009), HSR subgrade construction (Preteseille, Lenoir, \& Gennesseaux, 2014), etc. The research on the risk management of HSR includes construction risks (Chen, Jiang, \& Ye, 2016; Qing, Rengkui, \& Jun, 2014), security risks (Brabie \& Andersson, 2009), train scheduling risks (Cascetta \& Coppola, 2016), etc. There are few studies on the competitive advantage about HSR projects.

Porter (1985) proposed the concept of competitive advantage, which refers to the attributes or capabilities that allow an organization to outperform its competitors in the "competing market" and to achieve market dominance over a certain period or higher than average profit levels. Barney (1986) believed that, due to the incompleteness of the "strategic factor market", some enterprises would gain a competitive advantage and excessive profit due to the existence of strong forecasting abilities or opportunities. $\mathrm{Li}$, B. Ragu-Nathan, and T. S. Ragu-Nathan (2006) pointed out that competitive advantage refers to the ability of an organization to create and maintain a defensive position that is superior to competitors.

Many scholars have carried out extensive and in-depth research on competitive advantage for contractors. Betts (1994) documented the results of a strategic-planning workshop undertaken for an Australian enterprise to develop a sustainable competitive advantage. Green et al. (2008) provided the dynamics capabilities framework to analyze how contractors continuously adapt to changing environments through an exploratory case study. Korkmaz and Messner (2008) explored the concepts of competitive positioning and continuity in the context of mode (cost, quality, innovation, and timing) and scope (segment, vertical, geographic, and industry) of competition for U.S. and Turkish contractors in international markets. L. Shen, Lu, Q. Shen, and Li (2003), Shen, Lu, and Yam (2006) focused on identifying the key competitiveness indicators and assessing a contractor's competitiveness. In addition, some researchers studied the relationship between contractors' competitive advantage and some certain variable, with examples such as innovation ( $\mathrm{Lu}, \mathrm{Liu}$, Rowlinson, \& Poon, 2013; Lim, Schultmann, \& Ofori, 2010), quality management (Jaafari, 2000), political risk management (Deng, Low, Li, \& Zhao, 2014; Chang, Hwang, Deng, \& Zhao, 2018a; Chang, Deng, Zuo, \& Yuan, 2018b), positive psychological capital (Toor \& Ofori, 2010), project safety (Rechenthin, 2004), decision-making style (Oyewobi, Windapo, \& Rotimi, 2016), equipment selection (Samee \& Pongpeng, 2016), and guanxi (Lin, Q. Chen, Liao, P. H. Chen, \& Cheng, 2018). However, the research about 
Table 1. Variables identified from the literature and pilot survey

\begin{tabular}{|c|c|c|}
\hline No. & Variables & Literature \\
\hline V1 & Tender price & Thompson and Coe (1997), Zekiri (2017) \\
\hline V2 & Financial performance & Wingwon and Piriyakul (2010) \\
\hline V3 & Financing capability & Grant (1991), Li and Ogunmokun (2001), Piercy, Kaleka, and Katsikeas (1998) \\
\hline V4 & Historical contract performance & $\begin{array}{l}\text { T. Obloj and K. Obloj (2006), Williams, Schnake, and Fredenberger (2005), } \\
\text { Goldberg, Cohen, and Fiegenbaum (2003) }\end{array}$ \\
\hline V5 & Social responsibility & $\begin{array}{l}\text { Du, Bhattacharya, and Sen (2011), Sousa Filho, Wanderley, and Gómez (2010), } \\
\text { Zhang, Cavusgil, and Roath (2003) }\end{array}$ \\
\hline V6 & Cultural difference & Soupata (2001), Lapersonne (2013) \\
\hline V7 & Productivity & Helms (1996), Istvan (1992) \\
\hline V8 & Internationalization & Lehrer, Schlegelmilch, and Behnam (2009), Yeung (1999) \\
\hline V9 & Cooperation ability & Wu, Lin, and Chien (2011), Alvarez and Barney (2001) \\
\hline V10 & Human resources & Stroh and Caligiuri (1998), Lado and Wilson (1994) \\
\hline V11 & Services & Gebauer, Gustafsson, and Witell (2011), Oliva and Kallenberg (2003) \\
\hline V12 & $\begin{array}{l}\text { Similar performance and } \\
\text { experience }\end{array}$ & $\begin{array}{l}\text { Fu, Drew, and Lo (2002), Doloi, Iyer, and Sawhney (2011), Holt, Olomolaiye, and } \\
\text { Harris (1995) }\end{array}$ \\
\hline V13 & Knowledge transfer & Oddou, Szkudlarek, and Osland (2013), Szulanski (2015) \\
\hline V14 & Competitive intelligence & Agnihotri and Rapp (2011), Seyyed-Amiri, Shirkavand, and Chalak (2017) \\
\hline V15 & None Accident history & Kim, Baek, and Yoon (2010), Kim and Yoon (2013) \\
\hline V16 & Technical responsiveness & J. S. Cook and L. L. Cook (2013), Williamson (2010) \\
\hline V17 & Technology transfer & Lin (2003), Mahoney and Qureshi (2006) \\
\hline V18 & Patents \& innovation & Berkowitz (1993), Tushman and Anderson (1986) \\
\hline V19 & Eligibility \& international criteria & K. Melykh and O. Melykh (2016), Zhang (2012) \\
\hline V20 & Resources integration & Dooley, Lupton, and O'Sullivan (2005), Pan, Zhang, Song, and Ai, (2018) \\
\hline V21 & Organizational flexibility & Combe and Greenley (2004), Sirmon, Hitt, and Ireland (2011) \\
\hline V22 & Project maturity & Tersine and Hummingbird (1995), Kumar and Motwani (1995) \\
\hline V23 & Marketing strategy & Kim, Jeon, and Hong (2012), Weitz (1978) \\
\hline V24 & Risk management capability & Bonabeau (2007), Elahi (2013), Leopoulos and Kirytopoulos (2004) \\
\hline
\end{tabular}

the competitive advantage of contractors on international HSR projects is very scarce. The existing studies about competitive advantage make it difficult to reflect upon the characteristics and the particularity of HSR projects.

In recognition of their contributions to the knowledge of competitive advantage, an initial list of the identified variables was compiled and synthesized. These variables have been referred to by many researchers in this field. Combined with the feedback from the pilot survey to be discussed later in this paper, Table 1 shows a list of 24 variables summarized from the related studies.

\section{Research methodology}

\subsection{Overall research frame}

The aim of this paper is to discriminate among and explain the critical variables contributing to the competitive advantages of international HSR contractors. To achieve this aim, the methodology of this paper is based on a literature review, pilot study, questionnaire survey, mean score, factor analysis and case study. The research framework was adapted from the research frameworks by Deng et al. (2014), Wang and Yuan (2011), and Deng, Low, Zhao, and Chang (2018).

\subsection{Questionnaire survey}

In accordance with the purpose of this research, a survey strategy was selected. Prior to the full-scale survey, a pilot study was performed with five professionals to test and refine the initial list of variables. All of the professionals have participated in several international construction projects and have more than 20 years of experience with the research in the field of international construction projects. There are two main aims of the pilot study: Aim (1) tests whether the 24 variables are appropriate for HSR contractors; Aim (2) tests whether the descriptions or interpretations of the survey items are appropriate. For Aim (1), the feedback was confirmative. For Aim (2), several useful suggestions about the survey items were proposed (such as revision and interpretation of the descriptions of variables 3, 6, 11, and 22). The survey questionnaire (see Appendix) was refined on the basis of their feedback. A 
Table 2. Distribution of the valid responses

\begin{tabular}{|c|c|c|c|}
\hline \multirow[t]{4}{*}{ Respondents } & Working regional segment & Number of effective responses & Percentage $(\%)$ \\
\hline & China (include 1 from Taiwan and 3 from Hong Kong) & 17 & 8.54 \\
\hline & Asia (except China ) & 3 & 1.51 \\
\hline & Europe & 7 & 3.52 \\
\hline \multirow[t]{6}{*}{ Academia } & North America & 7 & 3.52 \\
\hline & Australia & 6 & 3.02 \\
\hline & Total & 40 & 20.1 \\
\hline & Southeast Asia & 34 & 17.09 \\
\hline & South Asia & 26 & 13.07 \\
\hline & Middle East & 29 & 14.57 \\
\hline \multirow[t]{3}{*}{ Practitioner } & Africa & 51 & 25.63 \\
\hline & Others & 19 & 9.55 \\
\hline & Total & 159 & 79.9 \\
\hline
\end{tabular}

Likert 5-point scale was used to elicit respondents' opinions about the importance of each variable, with 1 being the least important and 5 being the most important. Brief descriptions of some unusual variables were also attached to the questionnaire to ensure that all the respondents were using the same definition for each of the variables. The respondents were encouraged to add additional variables that were not mentioned in the list according to their experience.

The survey was conducted from November to December 2017. A total of 554 questionnaires were distributed to professionals in the industry and academia with relevant experience and knowledge on the topic. A total of 216 responses were received of which 199 responses were valid (valid response rate is $35.92 \%$ ), which was acceptable and adequate for data analysis (Akintoye, 2000; Hwang, Zhao, \& Yu, 2016; Chang et al., 2018b). Among the 199 valid responses, 40 were from academics and 159 were from practitioners. The distribution of the effective responses in the survey is shown in Table 2. The projects they worked on were distributed across Asia, African, Europe, etc. The distribution of the experience of practitioners is shown in Table 3. A majority of the practitioners have more than 10 years of experience in the railway industry or international construction market (70.44\% and 59.12\%, respectively).

\subsection{Data analysis method}

To identify critical variables contributing to competitive advantages in international HSR projects, several statistical analysis methods, typically including the mean score
(MS) method and factor analysis, are adopted for data analysis. The data analysis was facilitated with SPSS 20.0.

\subsubsection{Mean score method}

The Mean Score Method for Likert-type data is a simple and effective ranking technique to identify the relative importance in previous construction management studies, as in Lu et al. (2008), Hwang, Zhao, and Do (2014), Zhao, Hwang, Low, and Wu (2015) and Deng et al. (2014, 2018). The variables were ranked according to their mean score values. The five-point Likert scale was used to calculate the mean score of each variable. The mean score determined the importance ranking of the variable.

\subsubsection{Factor analysis}

Factor analysis is used to address the problem of analyzing the interrelationships among a large number of variables (e.g., questionnaire responses) by defining a set of common underlying dimensions, known as factors (Wang \& Yuan, 2011; Deng \& Low, 2014; Shen \& Liu, 2003). Factor analysis was used to review the underlying relationship between the variables contributing to competitive advantages of international HSR contractors. Various tests are required to confirm the appropriateness of factor analysis.

Two main issues should be considered before the factor analysis: (1) the size of samples, and (2) the factorability (Pallant, 2010). In terms of sample size, Hair, Anderson, Tatham, and Black (1998) recommended that the ratio of sample size to variables should be larger than $5: 1$, while in this study the ratio is larger than $8: 1$. In terms of factor-

Table 3. Distribution of the experience of practitioners

\begin{tabular}{|l|c|c|c|c|c|}
\hline \multicolumn{1}{|c|}{ Experience of practitioners } & $<5$ years (\%) & $5-10$ years (\%) & $10-15$ years (\%) & $15-20$ years $(\%)$ & $>20$ years $(\%)$ \\
\hline $\begin{array}{l}\text { Total working experience in the } \\
\text { railway industry (in years) }\end{array}$ & 10.06 & 19.5 & 27.67 & 32.08 & 10.69 \\
\hline $\begin{array}{l}\text { Experience in international } \\
\text { construction market (in years) }\end{array}$ & 14.47 & 26.41 & 37.74 & 16.35 & 5.03 \\
\hline
\end{tabular}


Table 4. Results of mean score ranking and exploratory factor analysis

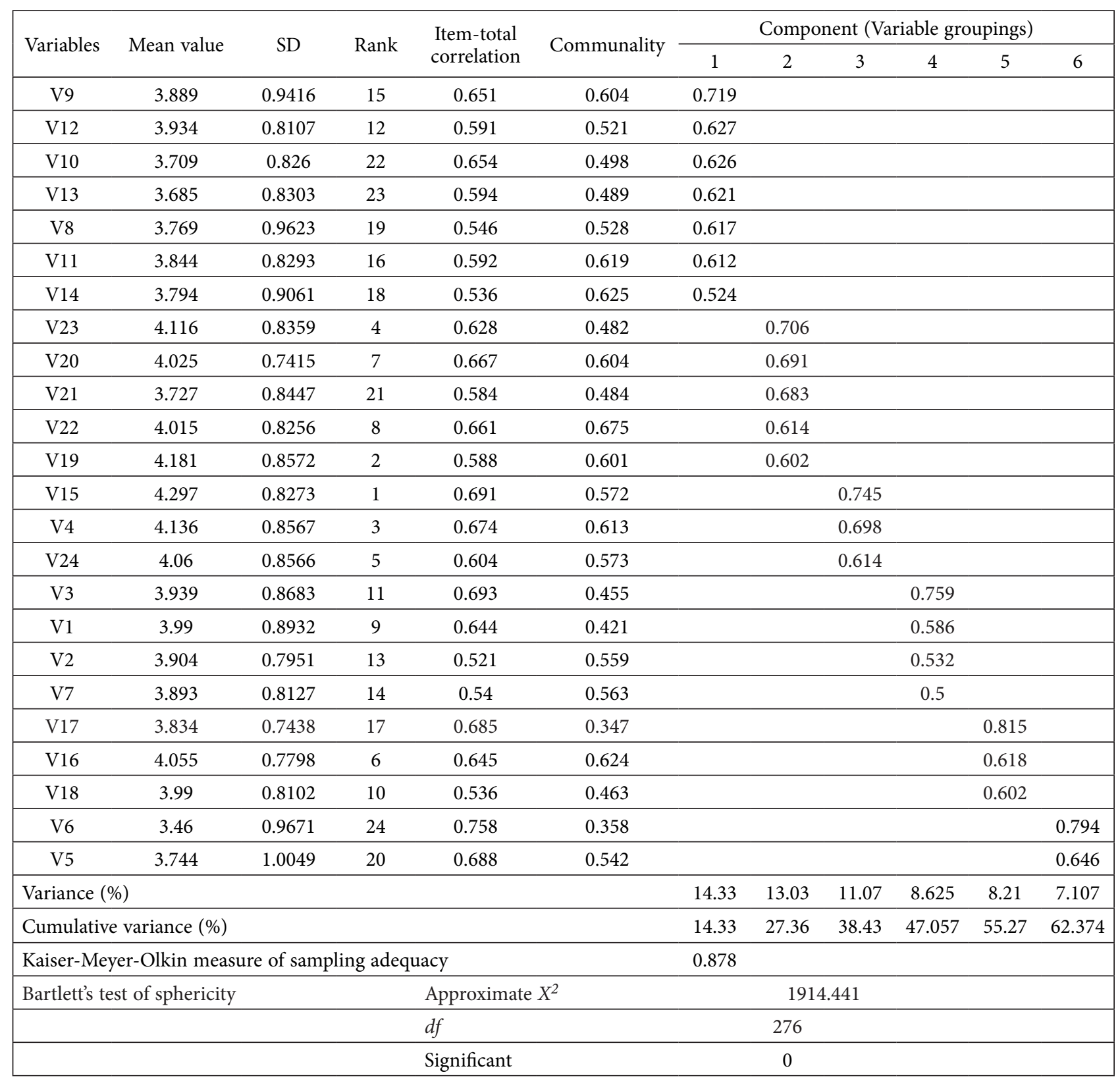

Note: The extract method is principal component analysis. Only loadings above 0.5 are shown.

The rotation method is Varimax with Kaiser normalization.

Extraction method: principal component analysis.

ability, the Item Correlation Matrix was tested using the Kaiser-Meyer-Olkin index (KMO > 0.5 (Kaiser, 1974)) and Bartlett' tests $(\mathrm{p}<0.05$ (Bartlett, 1954)). The results are shown in Table 4.

Cronbach's alpha coefficient was used to test the reliability of the 5-point Likert scale in this study. The Cronbach's alpha is 0.916 (F-statistic $=12.809$, significance level $=0.000$ ), higher than 0.7 , which indicated that the samples are reliable for factor analysis (Hair et al., 1998). The orthogonal (varimax) rotation was also employed in SPSS. The internal consistency of variables was tested using Cronbach's alpha > 0.7 (Hair et al., 1998), and item-to- tal correlation > 0.3 (Kumar, Scheer, \& Steenkamp, 1995), which is shown in Table 4.

\section{Research findings and discussions}

\subsection{Ranking of the variables}

In this section, the aim is to identify and analyze the variables that have a significant impact on competitive advantages in international HSR projects. According to the Mean Score Method, a variable with a relatively high mean value potentially has a higher influence. In Table 4, it can be clearly seen that the mean values of the 24 vari- 
ables ranged from 4.2965 to 3.4596 , which means that the respondents consider, in general, all of the variables to be critical to competitive advantages for international HSR contractors. The top six variables are of the most importance, namely, (1) None Accident History, (2) Eligibility \& International Criteria, (3) Contract Reputation, (4) Marketing Strategy, (5) Risk Management Capability, and (6) Technical Responsiveness. These six variables are elaborated as follows.

\subsubsection{None accident history}

According to the ranking of the mean values, None Accident History is the most important variable for the competitive advantage of international HSR contractors (with a mean value of 4.2965). This variable means that there were no accidents during a contractor's previous projects over a specific period. In international HSR projects, safety plays a very important role in affecting competitive advantage. In the Zheng-Wan HSR project, the collapse of a bridge pier under construction left 3 people dead and 3 injured seriously, which made a negative impact on the competitiveness of Chinese contractors in the ongoing bidding of HSR project in California. In Brazilian HSR projects, it is clearly pointed out that any contractor with heavy casualties in the last 5 years is not qualified to tender. Several Chinese and European contractors with accident histories failed to tender. In addition to HSR construction accidents, HSR operation accidents also have an impact on the contractor's competitive advantage as the mode of BOT is much popular in international HSR projects (e.g. "JakartaBandung" in Indonesia, "Mecca-Medina" in Saudi Arabia, "Mumbai-Ahmedabad" in India, etc.). Although 7 years had passed since the Yong-Wen HSR operation accident in China, the first stage of financing for the China-USA Nevada HSR Project was still suspended due to the consideration of "None Accident History". In the Yong-Wen HSR accident, the crash of two high-speed trains left 40 people dead and 172 injured, which reduces the competitiveness of Chinese HSR contractors in the international market. Similarly, 14 people died, and 44 were injured in the HSR derailment accident in France in 2015, severely affecting the competitiveness of French high-speed contractors in bidding for the HSR project in Taiwan. According to the CAS-HEAR model (Kim et al., 2010), there are three causes of HSR accidents: (1) human failure (errors or violations by people), (2) technical failure (hardware or software failure), and (3) external intrusion (e.g., pedestrians or obstacles on railway tracks, terrorist attacks, etc.). In the research of Kim and Yoon (2013), an investigation of 80 railway accidents in the UK was conducted, the results of which revealed a high correlation between HSR accidents and technical failures. Therefore, accident history usually plays the most important role in competitive advantage in international HSR projects. The variable, None Accident History, could be measured by the number of accidents and casualties.

\subsubsection{Eligibility \& international criteria}

This variable ranked second (with a mean value of 4.1809), and refers to the contractor being eligible for the project by meeting the requirements of the owner, or by being certified according to international criteria. Eligibility and international criteria could increase the probability of winning the competition between international contractors.

In detail, international eligibilities can help with market entry and technical barrier abatement. Entry-class eligibility is essential in competition. ISO and other technical standards are basic eligibilities. In the Bangladesh project, the bidder must be a member of JICA (Japan International Cooperation Agency). Criteria related to financing or the environment may need to be met, as well. Some optional criteria, such as LEED (Leadership in Energy and Environmental Design), can improve social value. These criteria are introduced in specific countries. For example, the environmental certification of Corporate Social Responsibility (CSR) played a positive role in Ukraine (K. Melykh \& O. Melykh, 2016). From another perspective those countries who established international standards set up the rules (Zhang, 2012). A Chinese company (China Railway Construction Corporation, CRCC) complied with US standards in the Saudi Arabia North-South Railway Project. According to the contract, CRCC holds the right of design and procurement; however, the detailed US standards made the American design company hold the priority position. In addition, CRCC failed to buy cheaper materials and equipment from China. This variable could be measured by the number and the applicability of the eligibilities.

\subsubsection{Historical contract performance}

This variable ranks No. 3 with a mean value of 4.1364 . Historical contract performance refers to the history of contract completion, which develops the reputation of the contractor. According to their history of contract performance, the international HSR contractor with a better reputation was more likely to win the bidding competition. The owners could perceive the integrity or dishonest behaviours of potential bidders (Fombrun, 1996) and then have an effective or emotional reaction, whether good or bad. T. Obloj and K. Obloj (2006) named the emotional reaction "reputation". Opportunism infects reputation, while fair, honest and predictable behaviours could enhance reputation. On the one hand, reputation reduces information asymmetries between sellers and buyers, and thus allows buyers to reduce concerns about the quality or uncertainty of the sellers' products or services (Williams et al., 2005). On the other hand, a high reputation enhanced predictability (Goldberg et al., 2003). Therefore, contractors that had a respectable history of contract performance could reduce transaction costs in future competition. Thus, Historical Contract Performance is an important variable in competitive advantage, and it can be measured by the completion or breach of past contracts. 


\subsubsection{Marketing strategy}

This variable ranked No. 4 with a mean value of 4.1156 . Marketing strategy is a series of selections: host country, target market, and the project. Marketing strategy maximized returns by market segmentation, an understanding of customer profitability, scenario pricing and targeted services. According to competitive intelligence, contractors selected a suitable project from the whole market, then presented resources and abilities as much as possible to increase their possibility of success in the international HSR market. Marketing strategy is the first step towards acquiring market share (Kim et al., 2012). With limited resources, the contractor will develop a segmentation strategy; however, not all projects will be treated equally. Weitz (1978) believed in spending more resources on profitable projects and less on money-losing ones. For profitable projects, contractors set a market strategy, or even customize products and services, according to customer's needs. In addition, cross-regional management and localization adjustments are important factors in international HSR projects.

\subsubsection{Risk management capability}

The variable Risk Management Capability ranks No. 5 with a mean value of 4.0603 . Risk management is a process that identifies loss exposure faced by an organization and selects the most appropriate technique for treating such exposures (Henebry \& Rejda, 1995; Chang et al., 2018b). The risk is generated, especially in HSR projects, by the less frequent and more inaccurate prediction of the future due to the fast pace of change (Wholey, \& Brittain, 1989). Moreover, a less frequent and more inaccurate prediction will increase the possibility of loss. HSR projects contain external political risk, global competitive risk, complex system risk and so on (Bonabeau, 2007). Risk management includes reducing the probability and the impact of risk incidents. Up to the strategic level, risk management capability generates competitive advantages by cultivating the risk awareness, flexibility, and agility of the organization. Fostering a culture of foresight, creativity, and communication are the strategic approaches of risk management (Ratcliffe, 2006). This index refers to the ability of the bidder to deal with project risk. It includes the identification of and response to the risks.

\subsubsection{Technical responsiveness}

This variable ranks No. 6 with a mean value of 4.0553 . Technical responsiveness means the degree of technical requirements that the contractor can satisfy. As a hightechnology industry, technical responsiveness is important in HSR projects. There is usually a list of requirements in the tender file of international HSR projects, in which a response regarding the technological level and deviation description are required. Higher responsiveness means more chances to win the bid. To enhance their responsiveness level, world-class contractors need to not only upgrade their technical capabilities but also identify cus- tomers' needs to make "individualized, but cost-effective response programs" (Souder \& Padmanabhan, 2016). The increasing uncertainty of the environment required worldclass contractors to be flexible enough to satisfy the demands of the changing market. Complex technological activities can help a contractor to become more flexible and meet the customer's needs in a changing marketplace. To sum up, a contractor with strong technical responsiveness can improve the reliability of service, and then improve customer satisfaction (Williamson, 2010). The variable of technical responsiveness could be measured by the number of tender requirements that the contractor can satisfy.

\subsection{Factor analysis}

Further analysis was conducted to reveal the underlying interrelationship among the 24 variables identified. All the variables were subjected to Factor Analysis (principal component analysis with Varimax Rotation). The KMO and Barlett's test, as well as a correlation matrix, all indicated that the variables met the requirements (as shown in 3.3.2). The data are appropriate for Factor Analysis.

The variables' loadings are shown in Table 4 . It can be clearly seen that each of the variables was weighted heavily on only one of the factors, and the loadings are all above the level of 0.5 (Hair et al., 1998). According to the Latent Root Criterion, a six-component solution was formed with a cumulative loading up to $62.374 \%$, which is higher than the guideline of $60 \%$ (Malhotra, 1996).

Spearman's rank correlation analysis was conducted to examine whether the relationships among variables within a factor exist to ensure the validity. The result of Spearman's rank correlation analysis showed that all the variables that measured a specific dimension of the competitive advantage factor were correlated with one another, and therefore they could measure the factor contributing to the competitive advantage of contractors in the certain dimension. The result of Spearman's rank correlation analysis between variables in Factor 1 is shown in Table 5. The results of correlation analysis between variables in other factors are not provided due to the space limitation.

For further interpretation, each factor shown in $\mathrm{Ta}$ ble 4 was given a name. The realistic meaning of a factor can be synthesized by combining the variables that had a relatively high loading on it (Deng \& Low, 2014). Capability-based and Resource-based competitive theories are combined to analyze the internal relationship among the variables under each factor. Then, a deeper understanding of the underlying factors that affect competitive advantage in international HSR projects could be attained. The 6 factors were named Glocalization (Factor 1), Marketing (Factor 2), Safety (Factor 3), Economics (Factor 4), Technology (Factor 5), and Responsibility (Factor 6). The six factors can be represented by the acronym, MR. STEG.

\subsubsection{Factor 1: Glocalization}

This factor, which contributed to $14.33 \%$ of the total variances, consists of seven variables (Internationalization, 
Table 5. Spearman's rank correlations for Factor 1 in Factor analysis

\begin{tabular}{|c|c|c|c|c|c|c|c|c|}
\hline & & V8 & V9 & V10 & V11 & V12 & V13 & V14 \\
\hline \multirow[t]{3}{*}{ V8 } & Correlation & 1.000 & $0.438^{* *}$ & $0.295^{* *}$ & $0.481^{* *}$ & $0.374^{* *}$ & $0.399^{* *}$ & $0.369^{* *}$ \\
\hline & Sig. (2-tailed) & & 0.000 & 0.000 & 0.000 & 0.000 & 0.000 & 0.000 \\
\hline & $N$ & 199 & 198 & 199 & 199 & 198 & 197 & 199 \\
\hline \multirow[t]{3}{*}{ V9 } & Correlation & & 1.000 & $0.421^{* *}$ & $0.471^{* *}$ & $0.320^{* *}$ & $0.388^{* *}$ & $0.470^{* *}$ \\
\hline & Sig. (2-tailed) & & & 0.000 & 0.000 & 0.000 & 0.000 & 0.000 \\
\hline & $N$ & & 198 & 198 & 198 & 197 & 196 & 198 \\
\hline \multirow[t]{3}{*}{ V10 } & Correlation & & & 1.000 & $0.328^{* *}$ & $0.321^{* *}$ & $0.330^{* *}$ & $0.388^{* *}$ \\
\hline & Sig. (2-tailed) & & & & 0.000 & 0.000 & 0.000 & 0.000 \\
\hline & $N$ & & & 199 & 199 & 198 & 197 & 199 \\
\hline \multirow[t]{3}{*}{ V11 } & Correlation & & & & 1.000 & $0.447^{* *}$ & $0.307^{* *}$ & $0.348^{* *}$ \\
\hline & Sig. (2-tailed) & & & & & 0.000 & 0.000 & 0.000 \\
\hline & $N$ & & & & 199 & 198 & 197 & 199 \\
\hline \multirow[t]{3}{*}{ V12 } & Correlation & & & & & 1.000 & $0.330^{* *}$ & $0.268^{* *}$ \\
\hline & Sig. (2-tailed) & & & & & & 0.000 & 0.000 \\
\hline & $N$ & & & & & 198 & 196 & 198 \\
\hline \multirow[t]{3}{*}{ V13 } & Correlation & & & & & & 1.000 & $0.488^{* *}$ \\
\hline & Sig. (2-tailed) & & & & & & & 0.000 \\
\hline & $N$ & & & & & & 197 & 197 \\
\hline \multirow[t]{3}{*}{ V14 } & Correlation & & & & & & & 1.000 \\
\hline & Sig. (2-tailed) & & & & & & & \\
\hline & $N$ & & & & & & & 199 \\
\hline
\end{tabular}

Note: ${ }^{* *}$ means that the correlation is significant at the 0.01 level (2-tailed).

Cooperation Ability, Human resources, Services, Similar Performance and Experience, Similar Performance and Experience, and Competitive Intelligence) with strong loadings. "Glocalization" has been coined to label this factor.

Glocalization is a portmanteau of globalization and localization (Brenne, 1998; Ritzer, 2003). It refers to the adaptation of international contractors to the particularities of the local culture in which they are serving. Integrating local culture into global management capability in international HSR projects could help contractors gain a competitive advantage.

On the one hand, Glocalization requires abundant experience to deal with different environments and cultural problems (Lehrer et al., 2009). This competitive advantage, Glocalization, was usually inherited from the mother corporation, which strengthens business integration to share the competitive advantage in different countries during the international integration process. On the other hand, contractors were likely to form a transnational alliance. The complementary behaviour of each partner in the alliance can improve the final competitive advantage (Szulanski, 2015). Glocalization transferred the resources and abilities across nations and project partners (Dunning \& Mcqueen, 2015). Partners of the transnational alliance networked together to form a relatively coherent socio-economic group to deal with the difficulties in the host countries, especially in developing countries or regions with rudimentary capital markets, limited financial disclosure, and weak contract law (Yeung, 1999). Due to the changing global political and economic environment, as well as the continuous increase in owners' requirements, Glocalization is very important for international HSR contractors.

\subsubsection{Factor 2: Marketing}

This factor, named Marketing, which contributed 13.034\% of the total variances, consists of five variables (Marketing Strategy, Eligibility \& International Criteria, Resources Integration, Organizational Flexibility, and Project Maturity) with strong loadings.

As a factor affecting competitive advantage, Marketing is used to create an opportunity and keep the owner sat- 
isfied during the provision of services in an international HSR project. In addition to using marketing strategy to get access to a certain project (discussed above), some specific organizational activities of the contractor were also valid for keeping the owner satisfied throughout the process. The environment of international HSR projects is complex and changeable, and efficient, marketing-based organization could help the integration of resources. In the Saudi Arabia North-South Railway Project, there were many problems, such as high temperature, inconvenient infrastructure in the desert, the confusing schedule of local partners, and a lack of ballast. CRCC established four function groups, eventually took some management measures, and completed the track-laying project on time.

Organizational flexibility is another requirement for valid marketing. International HSR contractors' organizational structure should adapt to the project characteristics. Organizational flexibility was a buffering mechanism for dealing with internal or external uncertainties. Dynamic matching between the organization and the environment was a good way to build a competitive advantage. More flexible organizations have higher learning and adaptive capabilities and have more organic structures to deal with complex jobs (Sirmon et al., 2011). Organizational flexibility was divided into structural flexibility, operational flexibility and strategic flexibility (Pressly, 2009). Structural flexibility refers to project managers making good use of restructuring to communicate internal pressures and withstand external ones. Operational flexibility refers to the ability of adjusted procedures to effectively operate in changing environments. It is a tool for solving problems, improving quality, developing the operational design, generating an idea and influencing aggressive practices (Combe \& Greenley, 2004). Strategic flexibility is the final dimension of organizational flexibility. In addition to organizational structure, the employee is another important part of organizational management. Effective employee management is viewed as a tacit management capability that facilitates organizational learning and development of employee that can generate a competitive advantage.

\subsubsection{Factor 3: Safety}

This factor was responsible for $11.068 \%$ of the total variances and consists of three variables (Historical Contract Performance, None Accident History, and Risk Management Capability). Factor 3 is named Safety.

Safety was the primary goal of HSR, as well as one of the most important factors of competitive advantage for international HSR contractors. HSR projects are significant infrastructure projects, especially International HSR projects. The large capacity of passenger transportation enhances the need for high safety requirements. Therefore, international HSR contractors could achieve competitive advantages from safety assurance.

The regular way to achieve safety goals is safety risk management (Zhang, Wu, Zhu, \& AbouRizk, 2017; Zhang, Chen, Li, Wu, \& Skibniewski, 2018). With the development of safety management skills, organizations can create a competitive advantage through more active attitudes and methods. Project contractors in the HSR sector could take different actions to deal with safety risk to acquire competitive advantages. There are high potential profits in the area of safety. Proactive organizations tend to turn challenges into opportunities (Carbonara \& Caiazza, 2010). A proactive strategy of safety risk management should provide an adequate return on capital to compensate for the added cost (Nocco \& Stulz, 2006). However, if a contractor can handle safety risks better than competitors (Palmer \& Wiseman, 1999), that contractor would have the competitive advantage of entering the market with both high safety risks and high returns. Those who can manage safety risks better, or recover faster than others, are winners in the market. Those who can handle safety risks better than their rivals could not only survive the disruption but also thrive by gaining market share. In other words, they can differentiate themselves from their competitors (Elahi, 2013).

\subsubsection{Factor 4: Economics}

This factor, named Economics, contributed $8.625 \%$ of the total variances and consists of four variables (Tender Price, Financial Performance, Financing capability, and Productivity) with strong loadings.

The contractor chases the interests. Economics is a non-negligible factor of competitive advantages. Tender price is one of the components of economic performance. A reasonable tender price can reach a balance between low cost and enough profit (Dehghan, Zenouzi, \& Albadvi, 2012). Low cost is the foundation of a low tender price. The low-cost advantage can be turned into high-returns under certain circumstances. The variation of project tender price reflects differences of the geographical character, the request for the particular market segment, time, order volume, warranty, and other factors (Zekiri, 2017). In conclusion, either high return with the same cost or the same return with a lower cost can build competitive advantage.

Financial performance indicates the company's operations during past projects (Wingwon \& Piriyakul, 2010). In the bidding of the Bangladesh railway project, total assets, total liabilities, net capital, current assets, current liabilities, net income, pre-tax profits and after-tax profits in the last 5 years had to be listed. Financial performance is an important indicator of competitive advantage.

\subsubsection{Factor 5: Technology}

This factor, named Technology, which contributed 8.21\% of the total variances, consists of three variables (Technical Responsiveness, Technology Transfer, and Patents \& Innovation) with strong loadings.

For international HSR projects, technology was an important and sensitive component. HSR is a high-tech industry. Key technology means heterogeneous technologies and patents. In the past, patents could help keep a competitive advantage by creating technical barriers (Berkowitz, 1993). However, with the acceleration of knowledge spread and technological progress, patents' useful life has 
been shortened (Tushman \& Anderson, 1986). Thus, organizations need to develop new competitive advantages to meet market requirements. France's HSR was the best in the world. However, in a recent report, the French National Audit Office mentioned that its technological advantages were being reduced by the stern HSR management system and a lack of technological innovation. The direct evidence was that France has not joined in the new HSR Signal Guidance Standard and Railway Network Management System in the EU. Exploratory learning will invent completely new technology. If innovation can perceive and seize new opportunities and adjust technology to the opportunities and the environment, then innovation could create competitive advantages (Harrigan \& Diguardo, 2017).

Furthermore, advanced technology, technological openness and post-project training will facilitate the transfer from technology to competitive advantage (Lin, 2003). Technological development is not distributed equally across the world. Contractors can import advanced technology through the advantages of late-entry (Capon \& Glazer, 1987). The Ethiopia Railway Project (Massie, 2012) was a good example of technology transfer. In this technology transfer case, China trained engineers and technicians from Ethiopia and Djibouti.

\subsubsection{Factor 6: Responsibility}

This factor was responsible for $7.107 \%$ of the total variances and consists of two variables (Social Responsibility, and Cultural Difference). Factor 6 is named Responsibility.

Responsibility is the organization's commitment to the strategic imperative to maximize long-term economic, societal and environmental well-being through business practices, policies, and resources (Du et al., 2011). In the Thailand HSR project, the exchange of Thai agricultural products and China's HSR technology was a kind of economic and social help. This strategic investment consists of the creation of well-being and positive advantages to society and the local community. It also consists of additional benefits to the organization, such as an enhanced reputation, more qualified employees, and a premium return (Sousa Filho et al., 2010). Macroscopically, the responsibility belongs to social marketing initiatives aimed at improving consumer well-being while achieving the organization's strategic goals, such as market development and increasing sales (Raghubir, Roberts, \& Lemon, 2010). Microscopically, consumers respond positively due to the effective trust derived from acknowledging the responsibility of the enterprise, while strong, long-term relationships are formed through affective trust (Agustin \& Singh, 2005). This relationship may help consumers to be tolerant of market motives. Social responsibility is the outcome of human interactions. Complex and strong social webs become an important barrier for competitors who find it too difficult to imitate (McWilliams, Van Fleet, \& Cory, 2001).

Another aspect of responsibility is related to culture. Culture in international projects refers to the community with common experiences that shape the way they un- derstand certain things. For example, Pablo Vázquez, the executive chairman of Spain's National Railways, made it clear that Spain should enter the Latin American market in particular. This is because the long colonial history of Latin America resulted in it having a culture similar to Spain's. Therefore, Spanish National Railways is involved in bidding for HSR contracts in Brazil and Mexico. Appropriate management of cultural differences can create competitive advantages because that cultural intimacy can contribute to psychological intimacy (Costa \& Bamossy, 1995). Therefore, to reduce the impact of cultural differences, pre-project cultural training is essential in international projects (Mornah \& Macdermott, 2016).

\subsection{Discussion}

In the global HSR market, there is fierce competition among international contractors (Siemens, Alstom, Bombardier, Kawasaki Kisen Kaisha, Talgo, China Railways Corporation) with the advantages of HSR technology. Therefore, it is very important to take advantage of the particularity of the international HSR project to improve the competitive advantage of HSR contractors in international HSR projects.

\subsubsection{The capability-based view of competitive advantage}

For the capability-based view of competitive advantage, three factors (Safety, Technology, and Economics) could cluster. In the HSR project of "Ankara-Istanbul" in Turkey, Safety, Technology, and Economics played important roles from the capability-based view. This project is $158 \mathrm{~km}$ in length but took more than eight years before it was officially opened in July 2014 because the owners of Turkey believe that safety is the most important thing and that only the European standard could guarantee safety. Therefore, all the technology and equipment (including design specification, signal, locomotive, rail, cement, rubber gasket, fasteners, even molds, etc.) needed to be certified under the Europe standard. These tasks greatly affected the economic performance of the contractor.

From this case, it can be seen that capability-based competitive advantage is affected by factors that are interactional and dynamically evolved. Teece and Pisano (1994) defined dynamic capabilities as the ability to integrate and reconfigure relevant capabilities within and outside of the enterprise to adapt to a rapidly changing environment. Teece, Pisano, and Shuen (1997) put forward a 3P (Process, Position, and Path) concept of dynamic capabilities, and asserted that dynamic capabilities were the basis of differentiated competitive advantage. The factors that affect dynamic capabilities are interactional, and a certain dynamic capability factor could influence the effect of other factors (Breznik \& Lahovnik, 2016). When the competitive environment changes, it is necessary to emphasize the dynamic ability to adapt in order to maintain a competitive advantage (Kuo et al., 2017). If the HSR contractor is unable to adapt to the changing international 
environment, them the competitive advantage of a certain capability may decline or disappear.

\subsubsection{The resource-based view of competitive advantage}

For the resource-based view of competitive advantage, three factors (Glocalization, Marketing, and Responsibility) could cluster. In the HSR project of "Jakarta-Bandung" in Indonesia, Glocalization, Marketing, and Responsibility played important roles from the resource-based view. In the competition for this project, China Railway Corporation (CRC) utilized the marketing strategy of uniting local, state-owned companies (Wijaya Karya, Kereta Api, Jasa Marga, Perkebunan Nusantara, etc.). On one hand, the establishment of the joint venture meant that the contractors were the core members of the community of shared interests, which greatly improved their status in the competition. On the other hand, this marketing strategy helped the international contractor reduce the difficulty of localization, which improved the Glocalization of the contractor. Furthermore, CRC promised to help Indonesia train the management and operators of the HSR, which involved bringing China's HSR technology and experience to Indonesia and sharing HSR development achievements with the Indonesian people. These behaviours that reflect corporate social responsibility enhance the contractor's competitive advantage.

From the "Jakarta-Bandung" case, it can be found that resource-based competitive advantage is affected by various factors (Glocalization, Marketing, and Responsibility) that interact with each other. Under a similar initial condition, the competitive advantage of contractors often originates from the use of structured and combined resources (Sirmon, Hitt, \& Ireland, 2007). The heterogeneity and interaction of different resources play an important role in the competitive advantage of enterprises (Barney \& Mackey, 2016; Kellermanns et al., 2014). Kull, Mena, and Korschun (2016) consider stakeholder marketing as an important method for improving the differentiation advantage and cost advantage. From the resource-based view, Corporate Social Responsibility could assist the firm in achieving a sustained competitive advantage (Jensen, Cobbs, \& Turner, 2016).

\section{Case study}

\subsection{Data collection}

To utilize the 6 underlying factors to evaluate the competitive advantage of international HSR contractors, a targeted survey about the Early Train Operator (ETO) project (part of the California High-Speed Railway System) was performed in January 2018. The main interviewees were 14 professionals or managers from 3 corporations ( 7 from China Railways Corporation, 5 from Beijing Railway Administration, and 2 from China Railway Eryuan Engineering Group Corporation), who took part in the tender of the ETO project in California. All of them have more than
15 years of experience and have participated in several international HSR projects. The project information and the first-hand data of bid-evaluations were collected and used in the analysis of this study.

\subsection{Project background}

The ETO project was part of the California High-Speed Railway Plan, in which the California High-Speed Rail Authority was planning, designing and building the first high-speed railway system from San Francisco to the Los Angeles (called the California High-Speed Rail System, with estimated investments of more than 60 billion dollars). The ETO contract would proceed in two phases. Phase 1 would be governed by a performance-based PreDevelopment Agreement, pursuant to which the Operator, specifically including its identified Key Personnel, would work alongside the Authority and its advisors on the design, development, and procurement of the commercial aspects of high-speed railway passenger train operations. In Phase 2, the Operator would be responsible for preparing and operating the initial system pursuant to a Franchise Agreement to be negotiated and executed. It should be consistent with the associated Financial Plan, developed at an appropriate time during Phase 1. For Phase 1, the estimated not-to-exceed amount was 30 million dollars for a proposed term of 6 years. The remuneration and term for Phase 2 would be negotiated during Phase 1 .

The bid invitation for the ETO project was composed of two parts: Request for Qualification (RFQ in April 2017) and Request for Proposal (RFP in October 2017). Five teams (China HSR ETO Consortium, DB International USA, FS First Rail Group, FS First Rail Group, Stagecoach Group plc, shown in Table 6) responded to the RFQ and were invited to participate in the RFP. Eventually, four teams, excluding Stagecoach Group plc, responded to the RFP.

\subsection{Data analysis and results}

To compare the competitive advantage of the teams on the basis of the factor analysis and the discussion above, the data of Qualification and Proposal Scores (from the RFQ and RFP Evaluation Committee) was normalized and used in the analysis, as shown in Table 7. Because Team STA did not respond to the RFP, the data analysis focused on the other four teams.

\subsubsection{From the capability-based view}

The item Past Performance evaluated based on the extent to which it presents relevant and verifiable evidence of good performance in contracts of similar size, scope or complexity, including the safety of operations, implementation of safety programmes and safety record, etc. From the scores it could be seen that Team FSF, which was led by an Italian consortium, ranked No. 1, while the scores of DBI and REN followed quite closely. This item appeared in the RFQ requirements. The Safety factor plays a very 
Table 6. Team compositions on the shortlist of RFQ

\begin{tabular}{|c|c|c|c|c|c|c|c|}
\hline Teams & \multicolumn{7}{|c|}{ Members } \\
\hline $\begin{array}{l}\text { China HSR ETO } \\
\text { Consortium } \\
(\mathrm{CHE})\end{array}$ & $\begin{array}{l}\text { China } \\
\text { Railway } \\
\text { International } \\
\text { Co., Ltd }\end{array}$ & $\begin{array}{l}\text { Beijing Railway } \\
\text { Administration }\end{array}$ & $\begin{array}{l}\text { China Railway } \\
\text { Eryuan } \\
\text { Engineering } \\
\text { Group Co., Ltd }\end{array}$ & China Rai & jay Corporation & & \\
\hline $\begin{array}{l}\text { DB International } \\
\text { USA (DBI) }\end{array}$ & $\begin{array}{l}\text { DB } \\
\text { International } \\
\text { USA Inc. }\end{array}$ & $\begin{array}{l}\text { Deutsche Bahn } \\
\text { AG }\end{array}$ & $\begin{array}{l}\text { Alternate } \\
\text { Concepts, Inc. }\end{array}$ & HSR, Inc. & & & \\
\hline $\begin{array}{l}\text { FS First Rail } \\
\text { Group (FSF) }\end{array}$ & $\begin{array}{l}\text { Ferrovie dello } \\
\text { Stato Italiane } \\
\text { S.P.A. }\end{array}$ & $\begin{array}{l}\text { FirstGroup } \\
\text { America Inc. }\end{array}$ & First Transit Inc. & Trenitalia & $\begin{array}{l}\text { CentoStazioni } \\
\text { S.p.A }\end{array}$ & $\begin{array}{l}\text { Italferr } \\
\text { S.p.A. }\end{array}$ & $\begin{array}{l}\text { McKinsey \& } \\
\text { Company, } \\
\text { Inc. }\end{array}$ \\
\hline Renfe(REN) & $\begin{array}{l}\text { RENFE- } \\
\text { Operadora }\end{array}$ & $\begin{array}{l}\text { Globalvia } \\
\text { Inversiones } \\
\text { S.A.U. }\end{array}$ & Adif & & & & \\
\hline $\begin{array}{l}\text { Stagecoach Group } \\
\text { plc (STA ) }\end{array}$ & $\begin{array}{l}\text { Stagecoach } \\
\text { Group plc }\end{array}$ & & & & & & \\
\hline
\end{tabular}

Table 7. Normalized scores of teams

\begin{tabular}{|llccccc|}
\hline & & \multicolumn{1}{c}{ Items } & CHE & DBI & FSF & REN \\
\hline \multirow{3}{*}{ Capability-Based View } & Past Performance (Safety) & 0.6 & 0.91 & 0.94 & 0.87 \\
& Cost and Interim Financial Plan (Economic) & 0.64 & 0.7 & 0.75 & 0.88 \\
& Train Operation (Technology) & 0.38 & 0.88 & 0.58 & 0.82 \\
& Mobilization, Integration and Understanding of & 0.38 & 0.82 & 0.57 & 0.8 \\
& the Service (Marketing) & 0.35 & 0.75 & 0.54 & 0.85 \\
Resource-Based View & Small Business Program (Responsibility) & 0.5 & 1 & 0.5 \\
& Glocalization & 0.48 & 0.84 & 0.73 & 0.79 \\
\hline
\end{tabular}

Note: Stagecoach Group plc did not respond to the RFP.

important role in the competition for international HSR projects.

The item Cost and Interim Financial Plan consisted of two parts (Interim Financial Plan and Cost Proposal), which were in the RFP requirements. FSF proposed the most competitive Cost Proposal, while REN, which was led by a Spanish consortium, provided the most attractive financing option. The California High-Speed Rail Authority (Authority) aimed to construct a large high-speed railway system that would cost more than 60 billion dollars, so financing was a tough task. The Authority strongly encouraged various forms of financing cooperation, although they had already gotten funding through the American Recovery and Reinvestment Act, Cap and Trade Proceeds, etc. The Economic factor played an important role in the ETO project.

The item Train Operation refers to the planning, organization, and management approach of train operation, which was used to test the technical level of the Teams. In this test, DBI, which was led by a German consortium, won out. The item Train Operation, which appeared in both the RFQ and RFP, means that, whether in the qualifi- cation phase or the proposal phase, the technology factor was of great concern to the ETO tenderer.

\subsubsection{From the resource-based view}

The item Small Business Program was the Authority's Small and Disadvantaged Business Enterprise Program, which established a 30 percent Small Business utilization goal, which is inclusive of a 10 percent Disadvantaged Business Enterprise goal and a three percent Disabled Veteran Business Enterprise goal for this Agreement. This requirement, which was driven by relevant laws and policies of the host country, was included in both the RFQ and the RFP (evaluated only in RFP). The Small Business Program meant the Teams should fulfill their social responsibility as a precondition, and Team REN won out on this item.

The item Mobilization, Integration, and Understanding of the Service consist of two parts: (1) Understanding of the Service (in the RFQ), and (2) mobilization and integration method (in the RFP). This item reflected the requirement of enterprise marketing levels. In this item, DBI ranked No.1 both in the RFQ and the RFP, while REN scored quite closely. 


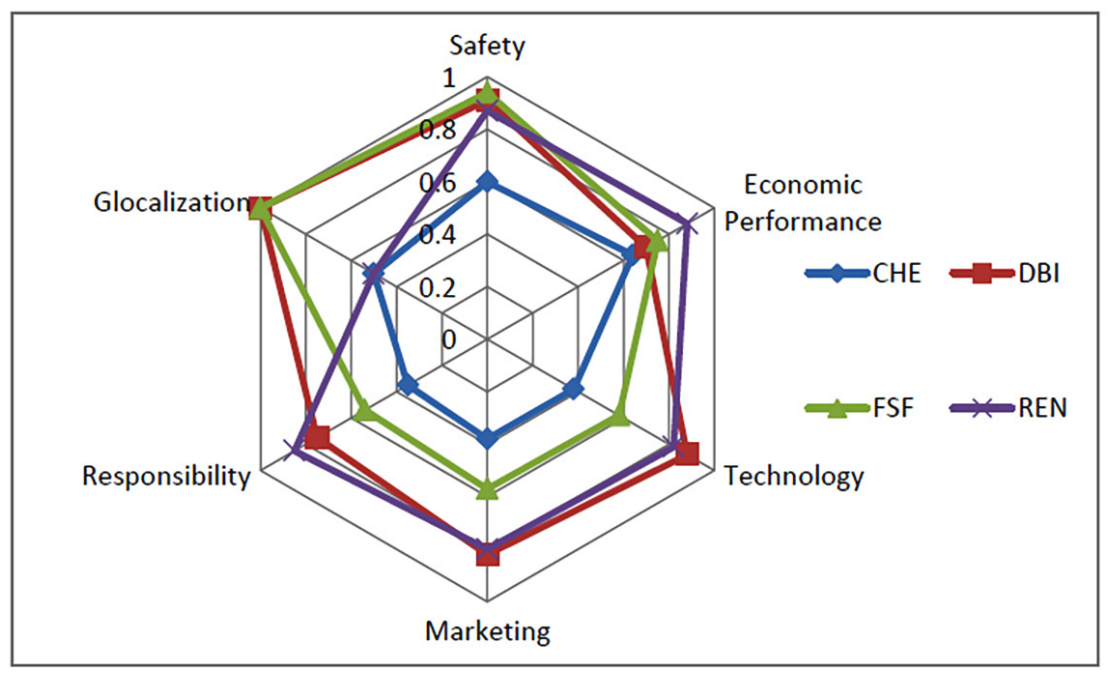

Figure 1. Radar of competitive advantage factors in ETO project

The item Glocalization evaluated the global teams' localization competence. It did not arise from the formal requirements of the tenderer but from the pressure of fierce competition. Table 6 shows the compositions of Teams. DBI and FSF invited influential companies from the host country to form the Team (scoring 1 subjectively), while $\mathrm{CHE}$ and REN did not (scoring 0.5 subjectively). The active participation of influential companies from the host country in the Team was an important reflection of Glocalization, which could improve the competitiveness of Team. Before the final session of face-to-face discussions, the composite scores of DBI and REN were quite close (with REN having a slight advantage), as could be observed from Figure 1. However, in the discussion session on October 4, 2017, DBI and REN scored 0.87 and 0.61 (Uniformed Scores), respectively, which may reflect that Glocalization was a key factor helping DBI to eventually win the ETO project.

\section{Conclusions}

Competitive advantages of international HSR contractors are influenced and determined by many variables. It is not only practical but also necessary to understand the critical variables. Wang and Yuan (2011) and Deng et al. (2018) presented a feasible way of identifying a few critical variables and deepening the understanding of the variables contributing to competitive advantages for international HSR contractors.

In this research, 24 variables with potential contribution to competitive advantages of international HSR contractors were identified by a literature review and pilot surveys. Through the approach of a questionnaire survey, the variables were ranked according to mean scores. The Top 6 variables are of the most important, namely, (1) No Accident History, (2) Eligibility \& International Criteria, (3) Contract Reputation, (4) Marketing Strategy, (5) Risk Management Capability, and (6)Technical Responsiveness.
By using Factor Analysis, the 24 variables were further categorized into 6 factors and named: Glocalization (Factor 1), Marketing (Factor 2), Safety (Factor 3), Economics (Factor 4), Technology (Factor 5), and Responsibility (Factor 6). These factors can be represented by the acronym MR. STEG. The results revealed that the 6 factors contribute $62.374 \%$ of the total variances affecting competitive advantages in international HSR projects. Therefore, the 6 factors represented the fundamental elements worth the consideration of contractors in forming and sustaining their competitive advantages in the international HSR market. Furthermore, the 6 factors could be divided between the Resource-based View (factors: Safety, Technology, and Economics) and the Capability-based View (factors: Glocalization, Marketing, and Responsibility). A case study of the Early Train Operator project of the California HSR was conducted, and the results indicated that the factor framework was suitable and tractable for the application.

The primary limitation of this research is that most respondents of the practitioner group mainly worked on railway projects in developing countries (or regions). This could be accepted because the international HSR market is generally the same for all the contractors. The feedback from the sample represents the essential aspect of opinions because of the rich experience of the respondents. Furthermore, the case study of ETO project of the California HSR in the USA demonstrates the factor framework is suitable for the application in developed countries. Finally, it is worth noting that this research focuses only on the critical variables contributing to the competitive advantages of international HSR contractors. Further research could reveal the interrelations of the variables and the dynamic interaction between them.

\section{Acknowledgements}

The authors would like to thank the respondents from both the industry and academia who have contributed to 
complete the survey questionnaires and the case survey used in this study.

\section{Funding}

This study was supported by the National Natural Science Foundation of China under Grant No. NSFC-71771052, NSFC-61503261, NSFC-71372199; Key Discipline of Management Science and Engineering of Hebei, China; Key research center of humanities and social sciences of Hebei (that is Construction Management Center of Shijiazhuang Tiedao University, China); and Soft Science Research Center of Hebei, China.

\section{Author contributions}

As the principal investigator of this project, Dr Yanliang Niu and Professor Xiaopeng Deng (corresponding author) were responsible for everything including the design and development of the research and the data analysis. Dr Limao Zhang was responsible for literature review and data interpretation. Professor Xiaochen Duan was responsible for data collection and analysis. All of them worked together in drafting this paper.

\section{Disclosure statement}

The authors would like to declare that they no competing financial, professional, or personal interests from other parties.

\section{References}

Abdul, R., Abdul, A., \& Wong, S. (2010). Competitive assets of Malaysian international contractors. Journal of Financial Management of Property and Construction, 15(2), 176-189. https://doi.org/10.1108/13664381011063458

Agnihotri, R., \& Rapp, A. (2011). Perspectives on competitive intelligence within business: A tactical tool for sales-people to gain a competitive advantage. Marketing Review, 11(4), 363380. https://doi.org/10.1362/146934711x13210328715948

Agustin, C., \& Singh, J. (2005). Curvilinear effects of consumer loyalty determinants in relational exchanges. Journal of Marketing Research, 42(1), 96-108.

https://doi.org/10.1509/jmkr.42.1.96.56961

Akintoye, A. (2000). Analysis of factors influencing project cost estimating practice. Construction Management and Economics, 18(1), 77-89. https://doi.org/10.1080/014461900370979

Alvarez, S. A., \& Barney, J. B. (2001). How entrepreneurial firms can benefit from alliances with large partners. The Academy of Management Executive, 15(1), 139-148. https://doi.org/10.5465/ame.2001.4251563

Barney, J. B. (1986). Organizational culture: can it be a source of sustained competitive advantage. Academy of Management Review, 11(3), 656-665. https://doi.org/10.2307/258317

Barney, J. B. (1991). Firm resources and sustained competitive advantage. Journal of Management, 17(1), 99-120. https://doi.org/10.1016/s0742-3322(00)17018-4

Barney, J. B., \& Mackey, A. (2016). Text and metatext in the resource-based view. Human Resource Management Journal, 26(4), 369-378. https://doi.org/10.1111/1748-8583.12123
Bartlett, M. S. (1954). A note on the multiplying factors for various $\chi 2$ approximations. Journal of the Royal Statistical Society, Series B, 16(2), 296-298.

https://doi.org/10.1111/j.2517-6161.1954.tb00174.x

Berkowitz, L. (1993). Getting the most from your patents. Research-Technology Management, 32(2), 26-31. https://doi.org/10.1080/08956308.1993.11670887

Betts, M. (1994). Sustainable competitive advantage for project-management consultants. Journal of Management in Engineering, 10(1), 43-51. https://doi.org/10.1061/(ASCE)9742-597X(1994)10:1(43)

Bonabeau, E. (2007). Understanding and managing complexity risk. MIT Sloan Management Review, 48(4), 62.

Brabie, D., \& Andersson, E (2009). On minimizing derailment risks and consequences for passenger trains at higher speeds. Journal of Rail and Rapid Transit, 223(6), 543-566. https://doi.org/10.1243/09544097jrrt271

Brenne, N. (1998). Global cities, glocal states: global city formation and state territorial restructuring in contemporary Europe. Review of International Political Economy, 5(1), 1-37. https://doi.org/10.1080/096922998347633

Breznik, L., \& Lahovnik, M. (2016). Dynamic capabilities and competitive advantage: Findings from case studies. Management: Journal of Contemporary Management Issues, 21(Special issue), 167-185.

Cañizares, M. P. M., Pita, A. L., \& Álvarez, A. G. (2015). Structure and topology of high-speed rail networks. Transport, 168(5), 415-424. https://doi.org/10.1680/jtran.13.00015

Capon, N., \& Glazer, R. (1987). Marketing and technology: A strategic coalignment. Journal of Marketing, 51(3), 1-14. https://doi.org/10.2307/1251644

Carbonara, G., \& Caiazza, R. (2010). How to turn crisis into opportunity: perception and reaction to high level of uncertainty in banking industry. Foresight, 12(4), 37-46. https://doi.org/10.1108/14636681011062988

Carpintero, S. (2011). The competitive advantages of the Spanish companies in the international toll road industry. Journal of Civil Engineering and Management, 17(4), 483-493. https://doi.org/10.3846/13923730.2011.625632

Cascetta, E., \& Coppola, P. (2016). Assessment of schedule-based and frequency-based assignment models for strategic and operational planning of high-speed rail services. Transportation Research Part A, 84, 93-108. https://doi.org/10.1016/j.tra.2015.09.010

Chang, T., Deng, X., Zuo, J., \& Yuan, J. (2018b). Political risks in Central Asian countries: Factors and strategies. Journal of Management in Engineering, 34(2), 04017059.

https://doi.org/10.1061/(ASCE)ME.1943-5479.0000588

Chang, T., Hwang, B. G., Deng, X., \& Zhao, X. (2018a). Identifying political risk management strategies in international construction projects. Advances in Civil Engineering, Article ID 1016384. https://doi.org/10.1155/2018/1016384

Chen, R., Jiang, P., \& Ye, X. (2016). Probabilistic analytical model for settlement risk assessment of high-speed railway subgrade. Journal of Performance of Constructed Facilities, 30(3), 04015047. https://doi.org/10.1061/(asce)cf.1943-5509.0000789

Combe, I. A., \& Greenley, G. E. (2004). Capabilities for strategic flexibility: a cognitive content framework. European Journal of Marketing, 38(11-12), 1456-1480. https://doi.org/10.1108/03090560410560191

Cook, J. S., \& Cook, L. L. (2013). Achieving competitive advantages of advanced manufacturing technology. Benchmarking for Quality Management \& Technology, 1(2), 42-63. https://doi.org/10.1108/14635779410063329 
Costa, J. A., \& Bamossy, G. J. (Eds). (1995). Marketing in multicultural world. Thousand Oaks, London, New Dehli: Sage Publications.

Dehghan, A., Zenouzi, B., \& Albadvi, A. (2012). An investigation on the relationship between service quality and customer satisfaction: In the case of CCG CO. International Business Research, 5(1), 3. https://doi.org/10.5539/ibr.v5n1p3

Deng, X., \& Low, S. P. (2014). Exploring critical variables that affect political risk level in international construction projects: Case study from Chinese contractors. Journal of Professional Issues in Engineering Education and Practice, 140(1), 04013002. https://doi.org/10.1061/(asce)ei.1943-5541.0000174

Deng, X., Low, S. P., Li, Q., \& Zhao, X. (2014). Developing competitive advantages in political risk management for international construction enterprises. Journal of Construction Engineering and Management, 140(9), 758-782.

https://doi.org/10.1061/(asce)co.1943-7862.0000836

Deng, X., Low, S. P., Zhao, X., \& Chang, T. (2018). Identifying micro variables contributing to political risks in international construction projects. Engineering, Construction and Architectural Management, 25(3), 317-334. https://doi.org/10.1108/ecam-02-2017-0042

Doloi, H., Iyer, K. C., \& Sawhney, A. (2011). Structural equation model for assessing impacts of contractor's performance on project success. International Journal of Project Management, 29(6), 687-695. https://doi.org/10.1016/j.ijproman.2010.05.007

Dooley, L., Lupton, G., \& O’Sullivan, D. (2005). Multiple project management: a modern competitive necessity. Journal of Manufacturing Technology Management, 16(5), 466-482. https://doi.org/10.1108/17410380510600464

Du, S., Bhattacharya, C., \& Sen, S. (2011). Corporate social responsibility and competitive advantage: Overcoming the trust barrier. Management Science, 57(9), 1528-1545. https://doi.org/10.1287/mnsc.1110.1403

Dunning, J. H., \& Mcqueen, M. (2015). The eclectic theory of international production: A case study of the international hotel industry. Managerial \& Decision Economics, 2(4), 197-210. https://doi.org/10.1002/mde.4090020401

Elahi, E. (2013). Risk management: the next source of competitive advantage. Foresight, 15(2), 117-131. https://doi.org/10.1108/14636681311321121

Flanagan, R., Lu, W., Shen, L., \& Jewell, C. (2007). Competitiveness in construction: a critical review of research. Construction Management and Economics, 25, 989-1000. https://doi.org/10.1080/01446190701258039

Fombrun, C. J. (1996). Reputation: realizing value from the corporate image. Massachusetts: Harvard Business School Press.

Fu, W. K., Drew, D. S., \& Lo, H. P. (2002). The effect of experience on contractors' competitiveness in recurrent bidding. Construction Management and Economics, 20(8), 655-666. https://doi.org/10.1080/0144619022000014060

Gebauer, H., Gustafsson, A., \& Witell, L. (2011). Competitive advantage through service differentiation by manufacturing companies. Journal of Business Research, 64(12), 1270-1280. https://doi.org/10.1016/j.jbusres.2011.01.015

Goldberg, A. I., Cohen, G., \& Fiegenbaum, A. (2003). Reputation building: small business strategies for successful venture development. Journal of Small Business Management, 41(2), 168-186. https://doi.org/10.1111/1540-627x.00074

Gou, B., Ge, X., \& Wang, S. (2016). An open-switch fault diagnosis method for single-phase PWM rectifier using a modelbased approach in high-speed railway electrical traction drive system. IEEE Transactions on Power Electronics, 31(5), 38163826. https://doi.org/10.1109/tpel.2015.2465299
Grant, R. M. (1991). The resource-based theory of competitive advantage. California Management Review, 33(3), 3-23. https://doi.org/10.2307/41166664

Green, S. D., Larsen, G. D., \& Kao, C. (2008). Competitive strategy revisited: contested concepts and dynamic capabilities. Construction Management and Economics, 26(1), 63-78. https://doi.org/10.1080/01446190701656174

Guzinski, J., Diguet, M., \& Krzeminski, Z. (2009). Application of speed and load torque observers in high-speed train drive for diagnostic purposes. IEEE Transactions on Industrial Electronics, 56(1), 248-256. https://doi.org/10.1109/tie.2008.928103

Hair, J. F., Anderson, R. E., Tatham, R. L., \& Black, W. C. (1998). Multivariate data analysis (5 $5^{\text {th }}$ ed.). London: Prentice Hall.

Harrigan, K. R., \& Diguardo, M. C. (2017). Sustainability of patent-based competitive advantage in the U.S. communications services industry. Journal of Technology Transfer, 42(6), 1334-1361. https://doi.org/10.1007/s10961-016-9515-2

Helms, M. M. (1996). Perspectives on quality and productivity for competitive advantage. TQM Magazine, 8(3), 5-10. https://doi.org/10.1108/09544789610118403

Henebry, K. L., \& Rejda, G. (1995). Principles of risk management and insurance. Journal of Risk \& Insurance, 62(4), 797799. https://doi.org/10.2307/253600

Holt, G. D., Olomolaiye, P. O., \& Harris, F. C. (1995). A review of contractor selection practice in the U.K. construction industry. Building and Environment, 30(4), 553-561. https://doi.org/10.1016/0360-1323(95)00008-T

Hwang, B. G., Zhao, X., \& Do, T. H. V. (2014). Influence of tradelevel coordination problems on project productivity. Project Management Journal, 45(5), 5-14. https://doi.org/10.1002/pmj.21445

Hwang, B. G., Zhao, X., \& Yu, G. S. (2016). Risk identification and allocation in underground rail construction joint ventures: Contractors' perspective. Journal of Civil Engineering and Management, 22(6), 758-767. https://doi.org/10.3846/13923730.2014.914095

Istvan, R. L. (1992). A new productivity paradigm for competitive advantage. Strategic Management Journal, 13(7), 525-537. https://doi.org/10.1002/smj.4250130705

Jaafari, A. (2000). Construction business competitiveness and global benchmarking. Journal of Management in Engineering, 16(6), 43-53. https://doi.org/10.1061/(asce)0742-597x(2000)16:6(43)

Jensen, J. A., Cobbs, J. B., \& Turner, B. A. (2016). Evaluating sponsorship through the lens of the resource-based view: The potential for sustained competitive advantage. Business Horizons, 59(2), 163-173. https://doi.org/10.1016/j.bushor.2015.11.001

Kaiser, H. F. (1974). An index of factorial simplicity. Psychometrika, 39(1), 31-36. https://doi.org/10.1007/bf02291575

Kellermanns, F., Walter, J., \& Crook, T. R. (2014). The resourcebased view in entrepreneurship: a content-analytical comparison of researchers' and entrepreneurs' views. Journal of Small Business Management, 54(1), 26-48.

https://doi.org/10.1111/jsbm.12126

Kim, D. S., \& Yoon, W. C. (2013). An accident causation model for the railway industry: Application of the model to 80 rail accident investigation reports from the UK. Safety Science, 60(12), 57-68. https://doi.org/10.1016/j.ssci.2013.06.010

Kim, D. S., Baek, D. H., \& Yoon, W. C. (2010). Development and evaluation of a computer-aided system for analyzing human error in railway operations. Reliability Engineering \& System Safety, 95(2), 87-98. https://doi.org/10.1016/j.ress.2009.08.005 
Kim, J. H., Lee, B. S., \& Lee, J. H. (2015). Development of 1-MW inductive power transfer system for a high-speed train. IEEE Transactions on Industrial Electronics, 62(10), 6242-6250. https://doi.org/10.1109/tie.2015.2417122

Kim, K. H., Jeon, B. J., \& Hong, S. J. (2012). Effective employment brand equity through sustainable competitive advantage, marketing strategy, and corporate image. Journal of Business Research, 64(11), 1207-1211. https://doi.org/10.1016/j.jbusres.2011.02.047

Korkmaz, S., \& Messner, J. I. (2008). Competitive positioning and continuity of construction firms in international markets. Journal of Management in Engineering, 24(4), 207-216. https://doi.org/10.1061/(ASCE)0742-597X(2008)24:4(207)

Kull, A. J., Mena, J. A., \& Korschun, D. (2016). A resource-based view of stakeholder marketing. Journal of Business Research, 69(12), 5553-5560. https://doi.org/10.1016/j.jbusres.2016.03.063

Kumar, A., \& Motwani, J. (1995). A methodology for assessing time-based competitive advantage of manufacturing firms. International Journal of Operations \& Production Management, 15(2), 36-53. https://doi.org/10.1108/01443579510080409

Kumar, N., Scheer, L. K., \& Steenkamp, J. B. E. M. (1995). The effects of supplier fairness on vulnerable resellers. Journal of Marketing Research, 32(1), 54-65.

https://doi.org/10.2307/3152110

Kuo, S. Y., Lin, P. C., \& Lu, C. S. (2017). The effects of dynamic capabilities, service capabilities, competitive advantage, and organizational performance in container shipping. Transportation Research Part A: Policy and Practice, 95, 356-371. https://doi.org/10.1016/j.tra.2016.11.015

Lado, A. A., \& Wilson, M. C. (1994). Human resource systems and sustained competitive advantage: A competency-based perspective. Academy of Management Review, 19(4), 699-727. https://doi.org/10.2307/258742

Lapersonne, A. H. H. (2013). Managing multiple sources of competitive advantage in a complex competitive environment. Future Studies Research Journal: Trends and Strategies, 5(2), 221-251. https://doi.org/10.7444/fsrj.v5i2.120

Lehrer, M. A., Schlegelmilch, B. B., \& Behnam, M. (2009). Competitive advantage from exposure to multiple national environments: The induced internationalization of born-multidomestic firms. European Journal of International Management, 3(1), 92-110. https://doi.org/10.1504/ejim.2009.022636

Leopoulos, V. N., \& Kirytopoulos, K. A. (2004). Risk management: a competitive advantage in the purchasing function. Production Planning \& Control, 15(7), 678-687. https://doi.org/10.1080/09537280412331298238

Li, L., \& Ogunmokun, G. O. (2001). Effect of export financing resources and supply-chain skills on export competitive advantages: implications for superior export performance. Journal of World Business, 36(3), 260-279. https://doi.org/10.1016/s1090-9516(01)00055-4

Li, S., Ragu-Nathan, B., \& Ragu-Nathan, T. S. (2006). The impact of supply chain management practices on competitive advantage and organizational performance. Omega, 34(2), 107-124. https://doi.org/10.1016/j.omega.2004.08.002

Lim, J. N., Schultmann, F., \& Ofori, G. (2010). Tailoring competitive advantages derived from innovation to the needs of construction firms. Journal of Construction Engineering and Management, 136(5), 568-580.

https://doi.org/10.1061/(ASCE)CO.1943-7862.0000151

Lin, B. W. (2003). Technology transfer as technological learning: a source of competitive advantage for firms with limited R\&D resources. R\&D Management, 33(3), 327-341.

https://doi.org/10.1111/1467-9310.00301
Lin, Y. H., Chen, Q., Liao, P. C., Chen, P. H., \& Cheng, S. (2018). The moderating effect of guanxi on the dynamic capacity and competitive advantage of Chinese international contractors. Advances in Civil Engineering, Article ID 3638152. https://doi.org/10.1155/2018/3638152

Lu, W., Liu, A. M. M., Rowlinson, S., \& Poon, S. W. (2013). Sharpening competitive edge through procurement innovation: perspectives from Chinese international construction companies. Journal of Construction Engineering and Management, 139(3), 347-351.

https://doi.org/10.1061/(ASCE)CO.1943-7862.0000614

Lu, W., Shen, L., \& Yam, M. C. H. (2008). Critical success factors for competitiveness of contractors: China study. Journal of Construction Engineering and Management, 134(12), 972-982. https://doi.org/10.1061/(asce)0733-9364(2008)134:12(972)

Mahoney, S. J., \& Qureshi, A. F. (2006). Technology transfer: How to make it a competitive advantage. Biopharm International, 19(11), 64-68.

Malhotra, N. K. (1996). Marketing research: An apply orientation ( $2^{\text {nd }}$ ed.). London: Prentice Hall.

Massie, J. (2012). Digestion and re-innovation: A lesson learned from China's high-speed rail technology-transfer agreements. Intellectual Property Brief, 3(1), 124-126.

McWilliams, A., Van Fleet, D., \& Cory, K. (2001). Raising rivals' costs through political strategy: An extension of resourcebased theory. Journal of Management Studies, 39, 707-723. https://doi.org/10.1111/1467-6486.00308

Melykh, K., \& Melykh, O. (2016). Implication of environmental certification and CSR for companies' sustainable performance in developing countries. Journal of Sustainable Development, 9(3), 160. https://doi.org/10.5539/jsd.v9n3p160

Miozzo, M., \& Dewick, P. (2002). Building competitive advantage: innovation and corporate governance in European construction. Research Policy, 31(6), 989-1008.

https://doi.org/10.1016/S0048-7333(01)00173-1

Mornah, D., \& Macdermott, R. (2016). Culture as a determinant of competitive advantage in trade. International Journal of Business and Economic Sciences Applied Research (IJBESAR), 9(1), 69-76.

Nocco, B. W., \& Stulz, R. M. (2006). Enterprise risk management: theory and practice. Journal of Applied Corporate Finance, 18(4), 8-20. https://doi.org/10.1111/j.1745-6622.2006.00106.x

Obloj, T., \& Obloj, K. (2006). Diminishing returns from reputation: Do followers have a competitive advantage?. Corporate Reputation Review, 9(4), 213-224.

https://doi.org/10.1057/palgrave.crr.1550029

Oddou, G., Szkudlarek, B., \& Osland, J. S. (2013). Repatriates as a source of competitive advantage: How to manage knowledge transfer. Organizational Dynamics, 42(4), 257-266. https://doi.org/10.1016/j.orgdyn.2013.07.003

Oliva, R., \& Kallenberg, R. (2003). Managing the transition from product to services. International Journal of Service Industry Management, 14(2), 160-172.

https://doi.org/10.1108/09564230310474138

Orozco, F. A., Serpell, A. F., Molenaar, K. R., \& Forcael, E. (2014). Modeling competitiveness factors and indexes for construction companies: Findings of Chile. Journal of Construction Engineering and Management, 140(4), B4013002. https://doi.org/10.1061/(asce)co.1943-7862.0000462

Oyewobi, L. O., Windapo, A., \& Rotimi, J. O. B. (2016). Relationship between decision-making style, competitive strategies and organisational performance among construction organisations. Journal of Engineering Design \& Technology, 16(4), 713-738. https://doi.org/10.1108/JEDT-04-2015-0025 
Öz, Ö. (2001). Sources of competitive advantage of Turkish construction companies in international markets. Construction Management and Economics, 19, 135-144. https://doi.org/10.1080/01446190010009988

Pallant, J. (2010). SPSS survival manual: A step by step guide to data analysis using SPSS. Buckingham: Open University Press.

Palmer, T. B., \& Wiseman, R. M. (1999). Decoupling risk taking from income stream uncertainty: a holistic model of risk. Strategic Management Journal, 20(1), 1037-1062.

https://doi.org/10.1002/(SICI)10970266(199911)20:11<1037::AID-SMJ67>3.0.CO;2-2

Pan, X., Zhang, J., Song, M., \& Ai, B. (2018). Innovation resources integration pattern in high-tech entrepreneurial enterprises. International Entrepreneurship and Management Journal, 14(s1), 51-66.

https://doi.org/10.1007/s11365-017-0464-5

Piercy, N. F., Kaleka, A., \& Katsikeas, C. S. (1998). Sources of competitive advantage in high performing exporting companies. Journal of World Business, 33(4), 378-393. https://doi.org/10.1016/s1090-9516(98)90023-2

Porter, M. E. (1985). Competitive advantage creating and sustaining superior performance. New York: Free Press.

Porter, M. E. (1990). The competitive advantage of nations. New York: Free Press.

Pressly, T. R. (2009). Combining strategic management and internal control processes: a recipe for entrepreneurial competitive advantage. Entrepreneurial Executive, 14, 25-40.

Preteseille, M., Lenoir, T., \& Gennesseaux, E. (2014). Structural test at the laboratory scale for the utilization of stabilized fine-grained soils in the subgrades of High-Speed Rail infrastructures: analytical and numerical aspects. Construction and Building Materials, 61,164-171. https://doi.org/10.1016/j.conbuildmat.2014.02.069

Qing, L., Rengkui, L., \& Jun, Z. (2014). Quality risk management model for railway construction projects. Procedia Engineering, 84, 195-203. https://doi.org/10.1016/j.proeng.2014.10.426

Raghubir, P., Roberts, J., \& Lemon, K. N. (2010). Why, when, and how should the effect of marketing be measured? A stakeholder perspective for corporate social responsibility metrics. Journal of Public Policy \& Marketing, 29(1), 66-77. https://doi.org/10.1509/jppm.29.1.66

Ratcliffe, J. S. (2006). Challenges for corporate foresight: towards strategic prospective through scenario thinking. Foresight, 8(1), 39-54. https://doi.org/10.1108/14636680610647138

Rechenthin, D. (2004). Project safety as a sustainable competitive advantage. Journal of Safety Research, 35(3), 297-308. https://doi.org/10.1016/j.jsr.2004.03.012

Ritzer, G. (2003). Rethinking globalization: glocalization/grobalization and something/nothing. Sociological Theory, 21(3), 193-209. https://doi.org/10.1111/1467-9558.00185

Rocha, J. M., Henriques, A. A., \& Calçada, R. (2015). Efficient methodology for the probabilistic safety assessment of HighSpeed railway bridges. Engineering Structures, 101, 138-149. https://doi.org/10.1016/j.engstruct.2015.07.020

Samee, K., \& Pongpeng, J. (2016). Structural equation model for construction equipment selection and contractor competitive advantages. KSCE Journal of Civil Engineering, 20(1), 77-89. https://doi.org/10.1007/s12205-015-0632-5

Seyyed-Amiri, N., Shirkavand, S., \& Chalak, M. (2017). Competitive intelligence and developing sustainable competitive advantage. AD-minister, 30, 173-194.

https://doi.org/10.17230/ad-minister.30.9

Shen, L., Lu, W., \& Yam, M. (2006). Contractor key competitiveness indicators: a china study. Journal of Construction Engi- neering and Management, 132(4), 416-424.

https://doi.org/10.1061/(ASCE)0733-9364(2006)132:4(416)

Shen, L., Lu, W., Shen, Q., \& Li, H. (2003). A computer-aided decision support system for assessing a contractor's competitiveness. Automation in Construction, 12(5), 577-587. https://doi.org/10.1016/S0926-5805(03)00020-7

Shen, Q., \& Liu, G. (2003). Critical success factors for value management studies in construction. Journal of Construction Engineering and Management, 129(5), 485-491. https://doi.org/10.1061/(asce)0733-9364(2003)129:5(485)

Sirmon, D. G., Hitt, M. A., \& Ireland, R. D. (2007). Managing firm resources in dynamic environments to create value Looking inside the black box. Academy of Management Review, 32(1), 273-292. https://doi.org/10.5465/amr.2007.23466005

Sirmon, D. G., Hitt, M. A., \& Ireland, R. D. (2011). Resource orchestration to create competitive advantage: Breadth, depth, and life cycle effects. Journal of Management, 37(5), 13901412. https://doi.org/10.1177/0149206310385695

Souder, W. E., \& Padmanabhan, V. (2016). Transferring new technologies from R\&D to manufacturing. Research-Technology Management, 5, 38-43. https://doi.org/10.1080/08956308.1989.11670612

Soupata, L. (2001). Managing culture for competitive advantage at united parcel service. Journal of Organizational Excellence, 20(3), 19-26. https://doi.org/10.1002/npr.1003

Sousa Filho, J. M. D., Wanderley, L. S. O., \& Gómez, C. P. (2010). Strategic corporate social responsibility management for competitive advantage. BAR - Brazilian Administration Review, 7(3), 294-309. https://doi.org/10.1590/s180776922010000300006

Stroh, L. K., \& Caligiuri, P. M. (1998). Strategic human resources: a new source for competitive advantage in the global arena. The International Journal of Human Resource Management, 9(1), 1-17. https://doi.org/10.1080/095851998341161

Szulanski, G. (2015). Exploring internal stickiness: Impediments to the transfer of best practice within the firm. Strategic Management Journal, 17(S2), 27-43. https://doi.org/10.1002/smj.4250171105

Teece, D. J., \& Pisano, G. (1994). The dynamic capabilities of firms: an introduction. Industrial and Corporate Change, 3(3), 537-556. https://doi.org/10.1093/icc/3.3.537-a

Teece, D. J., Pisano, G., \& Shuen, A. (1997). Dynamic capabilities and strategic management. Strategic Management Journal, 18(7), 509-533. https://doi.org/10.1002/(SICI)10970266(199708)18:7<509::AID-SMJ882>3.0.CO;2-Z

Tersine, R. J., \& Hummingbird, E. A. (1995). Lead-time reduction: the search for competitive advantage. International Journal of Operations \& Production Management, 15(2), 8-18. https://doi.org/10.1108/01443579510080382

Thompson, K. N., \& Coe, B. J. (1997). Gaining sustainable competitive advantage through strategic pricing: selecting a perceived value price. Pricing Strategy \& Practice, 5(2), 70-79. https://doi.org/10.1108/09684909710163629

Tiong, R. L. K. (1995). Competitive advantage of equity in BOT tender. Journal of Construction Engineering and Management, 121(3), 282-289. https://doi.org/10.1061/(asce)0733-9364(1995)121:3(282)

Toor, S. U. R., \& Ofori, G. (2010). Positive psychological capital as a source of sustainable competitive advantage for organizations. Journal of Construction Engineering and Management, 136(3), 341-352. https://doi.org/10.1061/(asce)co.1943-7862.0000135

Tushman, M. L., \& Anderson, P. (1986). Technological discontinuities and organizational environments. Administrative Science Quarterly, 31(3), 439-465.

https://doi.org/10.2307/2392832 
Wang, J., \& Yuan, H. (2011). Factors affecting contractors' risk attitudes in construction projects: Case study from China. International Journal of Project Management, 29(2), 209-219. https://doi.org/10.1016/j.ijproman.2010.02.006

Weitz, B. A. (1978). The relationship between salesperson performance and understanding of customer decision making. Journal of Marketing Research, 15(4), 501-520. https://doi.org/10.2307/3150621

West, R. C. (1992). Improving international competitiveness. Journal of Professional Issues in Engineering Education and Practice, 118(2), 107-112.

https://doi.org/10.1061/(ASCE)1052-3928(1992)118:2(107)

Wholey, D. R., \& Brittain, J. (1989). Characterizing environmental variation. Academy of Management Journal, 32(4), 867882. https://doi.org/10.2307/256572

Williams, R. J., Schnake, M. E., \& Fredenberger, W. (2005). The impact of corporate strategy on a firm's reputation. Corporate Reputation Review, 8(3), 187-197. https://doi.org/10.1057/palgrave.crr.1540249

Williamson, P. J. (2010). Supplier strategy and customer responsiveness: Managing the links. Business Strategy Review, 2(2), 75-90. https://doi.org/10.1111/j.1467-8616.1991.tb00153.x

Wingwon, B., \& Piriyakul, M. (2010). Antecedents of PLS path model for competitive advantage and financial performance of SMEs in Thailand. African Journal of Marketing Management, 2, 123-135.

Wu, H., Lin, Y., \& Chien, F. L. (2011). A study on the relationship among supplier capability, partnership and competitive advantage in Taiwan's semiconductor industry. International Journal of Electronic Business Management, 9(2), 122.

Wu, Y., Jiang, B., \& Shi, P. (2016). Incipient fault diagnosis for T-S fuzzy systems with application to high-speed railway traction devices. IET Control Theory \& Applications, 10(17), 2286-2297. https://doi.org/10.1049/iet-cta.2015.1320

Yeung, W. C. (1999). The internationalization of ethnic Chinese business firms from Southeast Asia: strategies, processes and competitive advantage. International Journal of Urban and Regional Research, 23(1), 88-102.

https://doi.org/10.1111/1468-2427.00181
Zekiri, J. (2017). The quality and the price of the products as factors for a competitive advantage in the companies in the Republic of Macedonia. Ecoforum Journal, 6(1), 10.

Zhang, C., Cavusgil, S. T., \& Roath, A. S. (2003). Manufacturer governance of foreign distributor relationships: do relational norms enhance competitiveness in the export market. Journal of International Business Studies, 34(6), 550-566. https://doi.org/10.1057/palgrave.jibs.8400051

Zhang, L., Chen, H., Li, H., Wu, X., \& Skibniewski, M. J. (2018). Perceiving interactions and dynamics of safety leadership in construction projects. Safety Science, 106, 66-78. https://doi.org/10.1016/j.ssci.2018.03.007

Zhang, L., Wu, X., Zhu, H., \& AbouRizk, S. M. (2017). Perceiving safety risk of buildings adjacent to tunneling excavation: An information fusion approach. Automation in Construction, 73, 81-101. https://doi.org/10.1016/j.autcon.2016.09.003

Zhang, N., Deng, X., Zhao, X., \& Chang, T. (2018) Exploring the sources of contractors' competitive advantage on international HSR construction projects. International Journal of Civil Engineering, 1-15. https://doi.org/10.1007/s40999-018-0373-1

Zhang, S. (2012). International competitiveness of China's wind turbine manufacturing industry and implications for future development. Renewable \& Sustainable Energy Reviews, 16(6), 3903-3909. https://doi.org/10.1016/j.rser.2012.03.006

Zhao, X., Hwang, B. G., Low, S. P., \& Wu, P. (2015). Reducing hindrances to enterprise risk management implementation in construction firms. Journal of Construction Engineering and Management, 141(3), 04014083.

https://doi.org/10.1061/(ASCE)CO.1943-7862.0000945

Zhao, Z., \& Shen, L. (2008). Are Chinese contractors competitive in international markets. Construction Management and Economics, 26, 225-236. https://doi.org/10.1080/01446190801905380

Zhao, Z., Zuo, J., \& Zillante, G. (2011). Situation and competitiveness of foreign project management consultancy enterprises in China. Journal of Management in Engineering, 27(4), 200209. https://doi.org/10.1061/(asce)me.1943-5479.0000060

\section{APPENDIX. Sample survey questionnaire}

\section{Basic Information}

1. Your employer

Academia: $\square$ University $\square$ Research Institute

Construction Industry: $\square$ Construction Enterprise $\square$ Consulting Firm

$\square$ Suppliers of Construction Materials, Structural Parts, or Equipment

Manufacturing Industry: $\sqrt{ }$ Companies about turning out locomotives and rolling stock

Rolling Stock Parts Plant

$\square$ Other

2. Profession

Academia: $\quad \square$ Prof $\square$ Associate Prof $\square$ Assistant professor/ Lecturer

Construction Company: $\square$ Senior manager $\square$ Department manager $\square$ Project manager

Manufacturing Company: $\square$ Senior manager $\square$ Department manager $\square$ Project manager

Others

3. How many years of work experience do you have?

$\square<5$ years $\square$ 5-10 years $\square 11-15$ years $\square 16-20$ years $\square>20$ years

4. ${ }^{*}$ Your company/university/institute is located in ? (Required) 


\section{Variables for the Competitive Advantage of HSR Project}

The questionnaire consists of 24 variables affecting competitive advantage of High-speed Railway project bidders. A 5 -point Likert scale (with 1 being the least important and 5 being the most important) is used to elicit your opinions about the importance of each factor. Please judge the importance based on your experience.

\section{Please click only one choice for each variable.}

\begin{tabular}{|c|c|c|c|c|c|c|}
\hline \multirow{2}{*}{ No. } & \multirow{2}{*}{ Variables } & \multicolumn{5}{|c|}{ Importance } \\
\hline & & 1 & 2 & 3 & 4 & 5 \\
\hline V1 & Tender Price & $\square$ & $\square$ & $\square$ & $\square$ & $\square$ \\
\hline V2 & Financial Performance & $\square$ & $\square$ & $\square$ & $\square$ & $\square$ \\
\hline V3 & Financing capability & $\square$ & $\square$ & $\square$ & $\square$ & $\square$ \\
\hline V4 & Historical Contract Performance ${ }^{1}$ & $\square$ & $\square$ & $\square$ & $\square$ & $\square$ \\
\hline V5 & Social Responsibility $^{2}$ & $\square$ & $\square$ & $\square$ & $\square$ & $\square$ \\
\hline V6 & Cultural Difference ${ }^{3}$ & $\square$ & $\square$ & $\square$ & $\square$ & $\square$ \\
\hline V7 & Productivity & $\square$ & $\square$ & $\square$ & $\square$ & $\square$ \\
\hline V8 & Internationalization ${ }^{4}$ & $\square$ & $\square$ & $\square$ & $\square$ & $\square$ \\
\hline V9 & Cooperation Ability ${ }^{5}$ & $\square$ & $\square$ & $\square$ & $\square$ & $\square$ \\
\hline V10 & Human resources & $\square$ & $\square$ & $\square$ & $\square$ & $\square$ \\
\hline V11 & Services $^{6}$ & $\square$ & $\square$ & $\square$ & $\square$ & $\square$ \\
\hline V12 & Similar Performance and Experience & $\square$ & $\square$ & $\square$ & $\square$ & $\square$ \\
\hline V13 & Knowledge Transfer & $\square$ & $\square$ & $\square$ & $\square$ & $\square$ \\
\hline V14 & Competitive Intelligence & $\square$ & $\square$ & $\square$ & $\square$ & $\square$ \\
\hline V15 & None Accident History & $\square$ & $\square$ & $\square$ & $\square$ & $\square$ \\
\hline V16 & Technical Responsiveness ${ }^{7}$ & $\square$ & $\square$ & $\square$ & $\square$ & $\square$ \\
\hline V17 & Technology Transfer ${ }^{8}$ & $\square$ & $\square$ & $\square$ & $\square$ & $\square$ \\
\hline V18 & Patents \& Innovation & $\square$ & $\square$ & $\square$ & $\square$ & $\square$ \\
\hline V19 & Eligibility \& International Criteria & $\square$ & $\square$ & $\square$ & $\square$ & $\square$ \\
\hline V20 & Resources Integration 9 & $\square$ & $\square$ & $\square$ & $\square$ & $\square$ \\
\hline V21 & Organizational Flexibility & $\square$ & $\square$ & $\square$ & $\square$ & $\square$ \\
\hline V22 & Project Maturity & $\square$ & $\square$ & $\square$ & $\square$ & $\square$ \\
\hline V23 & Marketing Strategy & $\square$ & $\square$ & $\square$ & $\square$ & $\square$ \\
\hline V24 & Risk Management Capability & $\square$ & $\square$ & $\square$ & $\square$ & $\square$ \\
\hline
\end{tabular}

If you have any question, please tell us.

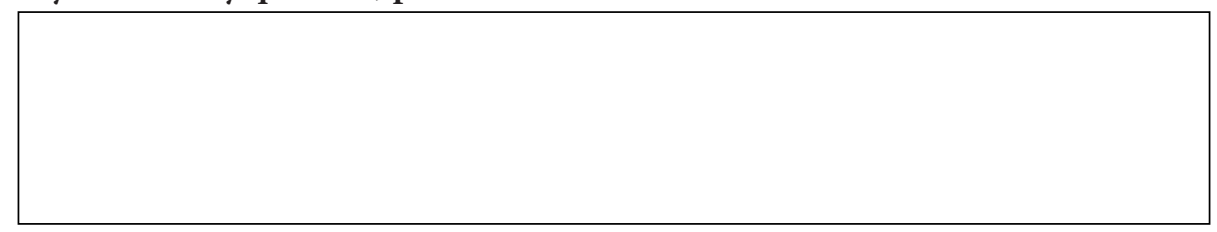

Thank You!

1 Historical contract performance refers to the completion of historical contracts by each partner.

2 Social responsibility means the proposal related to environment-friendly activities, health care, charity etc. during the project life cycle.

3 Cultural difference means the gap between home country and host country.

4 Internationalization means the quantity and quality of overseas business in the project company, including business in the host country such as establishing a subsidiary, undertaking local projects and so on.

5 Coordination ability refers to the ability of the joint venture members working together with each other and the ability of joint venture cooperating well with the government, bank, supplier, etc.

6 Services mean the whole project proposal, including design, installation, construction, after-sale and staff-training.

7 Technical responsiveness means how many requirements that the bidder can reach, and the degree of the accomplishments.

8 Technology transfer means the bidder transfer the key HSR technology to the tender.

9 Resources integration means there are adequate resources including human resources, finance resources and equipment resources to support the project. 